\title{
Knockdown of immature colon carcinoma transcript-I inhibits proliferation of glioblastoma multiforme cells through Gap 2/mitotic phase arrest [Expression of concern]
}

\author{
Xie R, Zhang Y, Shen C, Cao X, Gu S, Che X. OncoTargets \\ and Therapy. 2015;8:1119-1127.
}

The Editor-in-Chief and Publisher of OncoTargets and Therapy wish to issue an Expression of concern for the above published article.

The Journal Editors received a letter from an investigator raising concerns regarding the published paper. The $5^{\prime}$-GCGG... shRNA control sequence used in the above study was found to be homologous to a TPD52L2-targeting shRNA. The same TPD52L2-targeting sequence was identified by the investigators in a number of articles which incorrectly used this sequence as a negative or non-targeting control.
OncoTargets and Therapy

\section{Publish your work in this journal}

OncoTargets and Therapy is an international, peer-reviewed, open access journal focusing on the pathological basis of all cancers, potential targets for therapy and treatment protocols employed to improve the management of cancer patients. The journal also focuses on the impact of management programs and new therapeutic agents and protocols on
Dove Medical Press attempted to contact the authors of the article and their affiliated institution regarding the use of the TPD52L2-targeting sequence in this study but received no response. As we were unable to make a definitive conclusion about the use of the shRNA control sequence, we would like to alert readers to these issues and allow them to reach their own conclusions. This decision follows the recommendations of the Committee on Publication Ethics (COPE).

The Editor and Dove Medical Press make every effort to ensure publication ethics are upheld and are committed to supporting the high standards of the OncoTargets and Therapy journal. patient perspectives such as quality of life, adherence and satisfaction. The manuscript management system is completely online and includes a very quick and fair peer-review system, which is all easy to use. Visit http://www.dovepress.com/testimonials.php to read real quotes from published authors. 